\title{
Key methods of increasing motivation in teaching foreign languages
}

\author{
Mekhriniso MAMAEVA ${ }^{1}$ Dilfuza UMURKULOVA ${ }^{2}$ \\ Tashkent Branch of Plekhanov Russian University of Economics \\ Trust Education Centre
}

\begin{tabular}{l} 
ARTICLE INFO \\
\hline Article history: \\
Received September 2020 \\
Received in revised form \\
15 November 2020 \\
Accepted 30 November 2020 \\
Available online \\
15 December 2020 \\
\hline
\end{tabular}

\section{Keywords:}

Developing inspiration

Education

Skills

Language students

Study

\begin{abstract}
In the article there discussed the problem of increasing motivation as a condition for the training of a competent specialist today. Definitions of motivation are proposed. The possibility of creating motivation as a desire to perform a specific task is shown. Motivation is a significant factor for understanding the success or failure of any complex task. In the article there considered different types of motivation, appraisals previous studies about the role of motivation in language education as well.

2181-1415/C 2020 in Science LLC.

This is an open access article under the Attribution 4.0 International (CC BY 4.0) license (https://creativecommons.org/licenses/by/4.0/deed.ru)
\end{abstract}

\section{Ключевые методы повышения мотивации при обучении иностранным языкам}

\section{Ключевые слова: \\ Развитие мотивации \\ Образование \\ Навыки \\ Языковые студенты \\ Исследование}

\begin{abstract}
АННОТАЦИЯ
В статье рассматривается проблема повышения мотивации как условия подготовки грамотного специалиста сегодня. Предложены определения мотивации. Определена факторы и условия формирования мотивации к изучению иностранных языков. Мотивация - важный фактор понимания успеха или неудачи любой сложной задачи. В статье также рассмотрены различные типы мотивации, даны оценки предыдущих исследований о роли мотивации в языковом обучении.
\end{abstract}

\section{INTRODUCTION}

\footnotetext{
${ }^{1}$ Lecture, Tashkent Branch of Plekhanov Russian University of Economics, Tashkent, Uzbekistan Email:mehriniso26@mail.ru

${ }^{2}$ Trust Education Centre Tashkent, Uzbekistan
} 
According to studies measuring competence and language learning behavior integrate three main components; integrative motivation, linguistic self-confidence and appraisal of the classroom environment. Integrative motivation refers to the sociocultural dimension of language learning. It is discussed in detail below, but can be generally described as the language learners' attitudes toward the speakers and culture of the target language. Linguistic self-confidence combines a variety of affective variables, the main components being language anxiety and language learners' self-esteem within the target language environment. [5] Appraisal refers to the learners' attitudes and perceptions of the language classroom, the language teacher, and the classroom materials. As some scientists found that the classroom environment contributes to motivation in unique but measurable ways. There identified several aspects to the classroom environment affecting student motivation.

Scientists identify and describe these elements of the classroom environment as the most important:

- rapport amongst students

- communities of practice inside and outside the classroom instructor evaluation

- students' perceptions of teachers' knowledge

- native vs. non-native teacher speakers course evaluation

- relevance of course materials

- students' perception of course materials to their language learning goals.

Factors of student appraisal in the classroom environment summarized by many scientists that even though instrumental motivation (i.e. driven by specific language achievement goals beyond the language classroom and explained further below) seemed to be operative within the participants of their study, integrative motivation seemed to be the most prominent variable motivating the students to learn.[1]

In a subsequent study, researchers reflected that it is possible that integrative motivation may be more prominent among students when there are short-term or situational goals within the language classroom environment, which would explain the lack of instrumental motivation contributing to the classroom context at any given time. However, Dornyei conceded that this is by no means a complete picture of the classroom environment and other variables may be present, immeasurable within this particular study: "It has been pointed out several times in the second language literature that the difficulty of understanding the exact nature of classroom events lies to a large extent in the complexity of the classroom. In order to find a scientific construct that would cover a large number of classroom phenomena, we applied a group dynamics-based approach." [1]

\section{MATERIALS AND METHODS DIFFERENT APPROACHES TO MOTIVATE STUDENTS}

As researches show there should be applied a group dynamics-based approach when discussing motivation and the other possible affective variables that the participant students bring to the classroom environment. However, the data analysis provides a detailed narrative approach to a cross-section of the individual participants and their casenarratives provide an overview of the students experience with respect to the linguistic and intercultural interactions in general.

Motivational self-system attempts to account for motivational factors external to the classroom experience. In recognizing that motivation is complex, recursive, psychological process, this model explains language-learning motivation within the context of the 
individual language learner. Understanding the motivational self helps in accounting for the context that the individual brings to the classroom and what they contribute to the classroom environment.[3] The three dimensions of the motivational self-system include the following:

- future proficiency goals "ought to";

- external learning influences learning experiences;

- prior language learning;

- refers to the language learning and proficiency goals of the individual language learner.

These goals may be integrative or instrumental in nature.

The "ought to" self refers to the smaller incremental achievement goals of the language learner. The "ought to" self includes completing homework assignments, classroom activities, and meeting course requirements. For example, an individual language learner knows that he or she "ought to" study vocabulary lists prior to taking a quiz or test so that they can improve their grade in the course. These smaller, incremental achievement goals are instrumental, not integrative, and are generally imposed upon the learner from an outside authority. The "ought to" self is more concerned with completion of the linguistic task than understanding the target language and culture. [2]

The final dimension incorporates the language learner's prior experiences and exposure to the language and culture before deciding to learn the language in the classroom. It may also include concurrent exposure to the language and culture while the student is taking coursework conceptualizations set a solid framework for the research because these three dimensions of the motivational self-system helps to describe student's language learning motivation. As mentioned previously, affective variables in the language learning include psycho-social/emotive characteristics such as risk-taking, attitude, personality, self-esteem, motivation, and anxiety in the foreign language classroom. [5] These characteristics are common to the human experience and studies indicate that they have an impact on language learners inside and outside of the classroom. Examining students' motivation qualitatively gives insight into motivational decline over time, if any other languages, which are a non-cognate language with a different orthographic system from English. These languages are perceived as more difficult to learn for English speakers.

Motivation has been a cornerstone for second language learning and second language acquisition research for many years. One of the greatest obstacles to researching topics such as motivation is the dynamic definition of the term itself. Yet, motivation seems to be a determining factor in students' decisions to continue their language learning, not aptitude alone. Motivation in language learning moves beyond language teaching techniques and aptitude. Motivation encompasses more in its construct than merely the way languages are taught to the learner and subsequent proficiency outcomes. [4] This construct includes the learners' individual differences (such as attitude, aptitude, effort, and anxiety), classroom context, and the socio-cultural environment of the classroom. It is difficult to box in the whole field of research in language learning motivation into a singular theoretical perspective because motivation concerns the complexity and multiplicity of human beings, their intentions, their behaviors and their intentions. Additionally, motivation is highly situational and contextual, reflecting the humanity of participants. In short, there are many reasons why people learn languages, and these reasons are often related to one's social, ethnic, and cultural place in the community at large. Motivation has 
shown to be a topic that is popular in second language acquisition. According to, motivation is "one of the most thoroughly examined areas of second language acquisition.". Its multiplicity, complexity, and highly contextual nature have made it difficult for researchers to provide one, monolithic definition of motivation. In an effort to give a clearer definition of motivation and its relationship to language learning, some scientists identify two types of motivation: integrative motivation and instrumental motivation. [3]

Integrative motivation describes a learner's desire to integrate themselves into the target language and culture. Instrumental motivation refers to the goals of the learner to use their knowledge of the target language and culture in the future. More specifically, they state: "The notion of an integrative motive implies that success in mastering a second language depends on a particular orientation on the part of the learner, reflecting a willingness or a desire to be like representative members of the "other" language community, and to become associated, at least vicariously, with that other community" [6] Integrative motivation describes the learner's desire to incorporate and integrate elements of the target language and culture, such as their behaviors, foods, and cultural practices into their own lives. This type of motivation reaches beyond the classroom and reflects an attitude shift of the language learner towards the target language and culture. It indicates that the learner has become more accepting of the 'otherness' displayed by the target language and culture and is identifying with this otherness by incorporating it into the learner's own identity.

Instrumental motivation describes and explores language learners' ultimate goals with the language. There categorized the goals of the students as a reflection of their instrumental motivations to learn the language and become proficient. The instrumental motivations classified in his study are defined into goals such as job acquisition in government, ease of travel to the region, and understanding of the culture and traditions of other nations.

\section{RESULTS AND ITS DISCUSSION}

The benefit of researching instrumental motivation is that it easily gives language teachers, curriculum developers and language programs clear insight into student needs. However, unlike integrative motivation, it does not necessarily help language understanding the language and culture of other countries. English as a language has a complex relationship between the written and spoken forms that is beyond the scope of the discussion here but serves as a valid instrumental motivation for many heritage learners to learn the language in the classroom even when they speak Russian in their family homes - it differs from the literary and scientific language. And teachers all the time should keep students motivated from classroom to classroom. Both categories of motivation are relevant.

It would be significant to add that some of the ways of motivation of students that people are usually quite willing to spend a great deal of time thinking and learning while pursuing activities they enjoy. What are the most motivating features of task content? Here are some ideas:

- Challenge: Humans like to be challenged, as evidenced by our continual fascination with crosswords, puzzles or computer games, and the same applies to taking risks if those are moderate. This means that tasks in which learners need to solve problems, discover 
something, overcome obstacles, avoid traps, find hidden information, etc. are always welcome.

Interesting content: a simple but effective way to raise task interest is to connect the topic with things that students already are interested or hold in esteem. For example, including prominent events or people from the youth culture can add an attractive dimension to the activity. Learning about, say, daily routines can become much more interesting by focusing on a famous pop star, trying to imagine what he/she does and does not do.

The novelty element: if something about the activity is new or different or unfamiliar or totally unexpected, this will certainly help to eliminate boredom.

The intriguing element: tasks which concern ambiguous, problematic, paradoxical, controversial, contradictory or incongruous material stimulate curiosity by creating a conceptual conflict that needs to be resolved.

The exotic element: most of the students like learning about places and people which are unique and have a certain amount of grandeur.

The fantasy element: tasks are inherently captivating if they engage the learner's fantasy. Everybody, children and adults alike, enjoy using their imagination for creating make-believe stories, identifying with fictional characters or acting out pretend play.

The personal element: there is something inherently interesting about learning about the everyday life of real people (I don't know why); this has been capitalized on by TV soap operas and their generally high viewing rates prove that the principle works. In a similar attitude, many stilted coursebook tasks can be made stimulating by personalizing them, that is, by relating the content to the learners' own lives.

Competition: the opportunity to compete can add excitement to learning tasks, regardless of whether the competition is for prizes (e.g. a packet of sweets) or merely for the satisfaction of winning. Make sure, therefore, that losers do not take it very seriously.

Tangible outcome: tasks which require learners to create some kind of a finished product as the outcome (e.g. student newsletter, a poster, a radio program, an information brochure or a piece of artwork) can engage students to an unprecedented extent.

\section{CONCLUSIONS}

Thus, we may conclude: extramural and extracurricular activity positively influences different active teaching methods and raises motivation to continue learning by boosting self-esteem and showing practical value of limited knowledge already obtained by student. The above-mentioned aspects of personal development influencing on the level of motivation.

To improve the level of motivation certain requirements to educational process should be taken into consideration:

- the use of authentic materials, articles and results of foreign scientist's research to share their experience in a foreign language with students while a naturally more challenging task for a student is more rewarding not only from linguistic point of view, but motivationally as well.

- information studied at the class or as a part of homework should be connected with future profession of the students. Despite the fact that a great part of students has no advanced level of foreign language, they are interested in different terms concerning their 
specialization and results of modern research. Therefore, it would be important to arrange seminars and lectures in student's professional spheres.

However, it is necessary to select resources thoroughly in accordance with students' level of knowledge and needs. All things considered, we may come to conclusion that development of students' abilities and motivation is rather difficult work, therefore, the whole process of education, both curricular and extracurricular should be thoroughly planned and improved on the basis of various information resources and technologies.

\section{REFERENCES}

1. Dornyei, Z. 'Creating a Motivating Classroom Environment'. In Cummins, J. and Davison, C. (Eds.) (2007) International Handbook of English Language Teaching. New York: Springer.

2. Dornyei, Z. 'Understanding L2 Motivation: On with the Challenge!'. The Modern Language Journal 78/4: 2004, 515 - 523.

3. Ellis Rod - Second Language Acquisition. HK: 1997.0xford University Press.

4. Eccles J.S. Motivational beliefs, values and goals. Cambridge, 2002. P.109-132.

5. Leila Anjomshoa, Firooz Sadighi. The importance of motivation in second language acquisition. International journal on studies in English language and literature. Volume 3. Issue 2. February, 2015.

6. Oxford, Rebecca, \& Jill Shearin. Language learning motivation: Expanding the theoretical framework. The Modern Language Journal 78, 1: 2014 12-28. 